\title{
Ultrastructural aspects of Myxidium giardi (Myxozoa, Myxosporea), parasite of the European eel Anguilla anguilla
}

\author{
Carlos Azevedo ${ }^{1, *}$, Jiří Lom $^{2}$, Laura Corral ${ }^{1}$ \\ ${ }^{1}$ Department of Cell Biology, Institute of Biomedical Sciences, University of Oporto, P-4000 Porto, Portugal \\ ${ }^{2}$ Institute of Parasitology, Czechoslovak Academy of Sciences, 37005 Ceské Budějovice, Czechoslovakia
}

\begin{abstract}
The ultrastructure of Myxidium giardi Cépède, 1906 (Myxosporea) from the gills of eels Anguilla anguilla was studied. Sporogenesis complies basically with the pattern known in polysporic myxosporeans, although in this species 1 or 2 spores may be formed within a pansporoblast. The valvogenic cells contain 2 kunds of microtubules with diameters of 21 to $25 \mathrm{~nm}$ and $15 \mathrm{~nm}$. The suture between the 2 valvogenic cells is formed by a septate desmosome. The sporoplasm, the cell membrane of which may be partly covered by a dense layer, contams 2 nuclei arranged in a diplokaryon and numerous sporoplasmosomes giving a negative Thiéry reaction.
\end{abstract}

\section{INTRODUCTION}

The first species of the genus Myxidium examined by transmission electron microscopy was $M$. lieberkühni (Lom \& de Puytorac 1965), followed by M. gasterostei (Uspenskaya 1969), M. zealandicum, which Hine (1980) justifiably synonymized with $M$. glardi (Hulbert et al. 1977), and recently $M$. rhodei (Dyková et al. 1987). These papers have shown that the structural and morphogenetic patterns of Myxidium fall in line with those found in other myxosporeans.

The data avallable on the ultrastructure of Myxidium giardi Cépède, 1906, a species of wide distribution and an important pathogen in eel culture, are, however, still insufficient. The spores were studied by Hine (1978) and Lo (1981) by scanning electron microscopy. The transmission electron microscope study by Hulbert et al. (1977) left many questions of sporogony and pansporoblast formation unanswered and the very brief account of Lo (1981) concerns the principal structures of mature spores only. We undertook a more detailed ultrastructural study of this parasite.

\footnotetext{
- Addressee for correspondence
}

\section{MATERIAL AND METHODS}

Infected adult fish Anguilla anguilla L. were collected in the lake region of Aveiro $(60 \mathrm{~km}$ south of Oportol and in the Rivers Douro and Ave, North Portugal.

Infected gill lamellae containing Myxidium trophozoites were excised, fixed for $3 \mathrm{~h}$ at $4{ }^{\circ} \mathrm{C}$ in $3 \%$ glutaraldehyde in $0.2 \mathrm{M}$ sodium cacodylate buffer $(\mathrm{pH}$ 7.4) and processed for transmission electron microscopy according to the method of Azevedo (1984). Ultrathin sections were examined in a JEOL $100 \mathrm{~B}$ or JEOL $100 \mathrm{CXII}$ transmission electron microscope operated at $60 \mathrm{kV}$.

For scanning electron microscopy, isolated spores removed from mature plasmodia in gill filaments were rapidly rinsed twice in seawater and fixed in a solution of $3 \%$ glutaraldehyde in $0.2 \mathrm{M}$ sodium cacodylate $(\mathrm{pH}$ 7.4) for $4 \mathrm{~h}$. The spores were dehydrated in ethanol, dried by the critical-point method, coated with carbon and gold palladium and examined in a JEOL 35C SEM.

For cytochemical studies, sections were placed on gold grids and treated according to the method of Thiéry (1967). 


\section{RESULTS}

In the gills, the parasite formed oval plasmodia, up to 1 by $2 \mathrm{~mm}$, located in the secondary gill lamellae (Fig. 1). They were covered by a single layer of branchial epithelium. The large plasmodia contained numerous vegetative nuclei, generative cells (Fig. 2) and sporogonic stages. Due to a certain degree of synchronization of development, some plasmodia contained stages of sporogony while in others mature or nearly mature spores prevailed.

Spores were formed in pansporoblasts; the actual union of pericyte and sporogonic cell was not observed, but the early stages of pansporoblast formation were recorded (Fig. 3). Pansporoblast cells differentiated into capsulogenic, vaivogenic and sporopiasmic celis. The latter could be identified in their early stages as they contained 2 nuclei. Examination of many ultrathin sections indicated that either 1 or 2 spores may be produced within a pansporoblast.

In mature spores, the sporoplasm with its 2 nuclei was located between the 2 polar capsules. The latter contained the polar filament with its 4 to 5 coils (Fig. 4) The spindle-shaped spores had distinct longitudinal ridges (Fig. 5). A dense, fuzzy material adhered to the surface of the shell valves (Fig. 6). The number of surface ridges as seen on equatorial transverse sections ranged from 12 to 21 on one shell valve, not including the prominent sutural edge.

In advanced sporoblasts and mature spores the sporoplasm had 2 nuclei (Fig. 7). In the early sporoblasts the 2 sporoplasmic nuclei, with peripherally located chromatin and a distinct nucleolus, were separated or touched at one point only. Later, the nuclei attached closely together across a gap of about $15 \mathrm{~nm}$. As a rule, they became very electron-dense with homogeneously distributed material. The relative positions of the 2 nuclei differed in different sections (Figs. 7,8 and 9).

The dense inclusions in the sporoplasm, or sporoplasmosomes (term by Lom et al. 1986), appeared in advanced sporoblasts. At first they were bound by a double membrane $11 \mathrm{~nm}$ thick separated by a thin layer of dense material (Fig. 10). They contained an eccentrically situated, heterogeneous dense material leaving a peripheral lucent crescent. The diameter of the sporoplasmosomes ranged from 130 to $170 \mathrm{~nm}$. In mature sporoplasms, the sporoplasmosomes (Fig. 11) ranged from 175 to $240 \mathrm{~nm}$. The simple envelope no longer had the appearance of a double membrane, and the inner contents were homogeneous with a peripheral lucent crescent. A negative Thiéry reaction indicated the absence of polysaccharide in the sporoplasmosomes.

Microtubules of diameter 21 to $25 \mathrm{~nm}$ were seen in all cells of the developing sporoblasts. Bundles of microtubules occurred close to the nuclei of valvogenic and sporoplasmic cells and were also found to ensheath the external tube (Fig. 12) They also occurred in the developing valvogenic cells running parallel to the suture between the 2 shell valves. This suture is the line of contact between the 2 valvogenic cells which forms when they have encircled the sporoplasm cell and the capsulogenic cells.

A septate desmosome appeared in close contact with the suture between the 2 valvogenic cells (Fig. 13). At this stage a bundle of thin microtubules about $15 \mathrm{~nm}$ in diameter appears close to the line of contact (Fig. 14). Each bundle consists of about 7 layers of microtubules irregularly interconnected by short arms (Fig. 14).

The septate desmosome is about 0.3 to $0.4 \mu \mathrm{m}$ wide and probably runs along the length of the suture. The membranes of the wide flanges of the valvogenic cell (Fig. 15) face each other at a distance of $20 \mathrm{~nm}$, spanned by a series of about 20 to 23 dense connections spaced at $20 \mathrm{~nm}$. Deep furrows appeared on the outer membrane of the valvogenic cell and these furrows were separated by about 20 to 30 longitudinally extending $15 \mathrm{~nm}$ microtubules. The bundles of these thin microtubules situated next to the suture later disappeared.

The valvogenic cell was transformed into the ribbed shell valve by condensation of its cytoplasm which became electron-dense and structureless. The cell membrane of the valve was underlain by a thick layer of electron-dense substance. The microtubules could no longer be discerned. The septa in the desmosome were never quite distinct (Fig. 16).

The degraded remnants of the pericyte cell clung to the surface of maturating spores (Figs. 6 and 17). The top of the ridges was covered by electron-dense substance and less electron-dense substance was wedged into the furrows.

Equatorial transverse sections through the spores (Fig. 18) showed that the cell membrane of the sporoplasm turned into a dense layer underlain by an additionally formed cell membrane. This could be found, however, just on one part of the circumference of the sporoplasm.

\section{DISCUSSION}

Myxidium giardi described in this paper revealed a wide variation in the number of surface ridges on one shell valve - 12 to 21 , the average being 13 to 16 . Similarly, Hine $(1978,1979)$ found an average in $M$. giardi ( $=M$. zealandicum) of 12 to 16 while the full range was 9 to 20 ridges on one shell valve. Lo (1981) reported 14 to 18 ridges from TEM studies, 12 from 


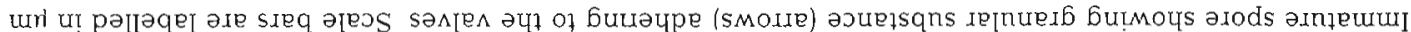

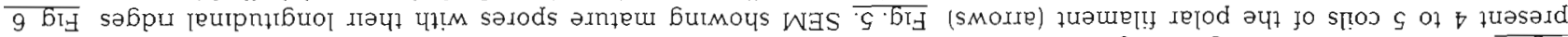

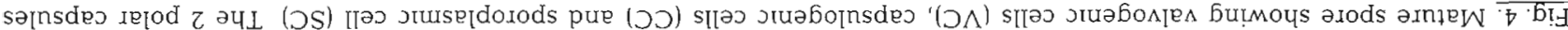

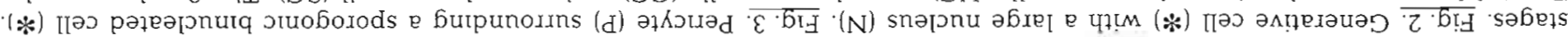

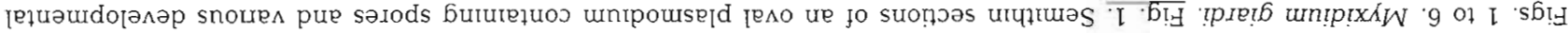
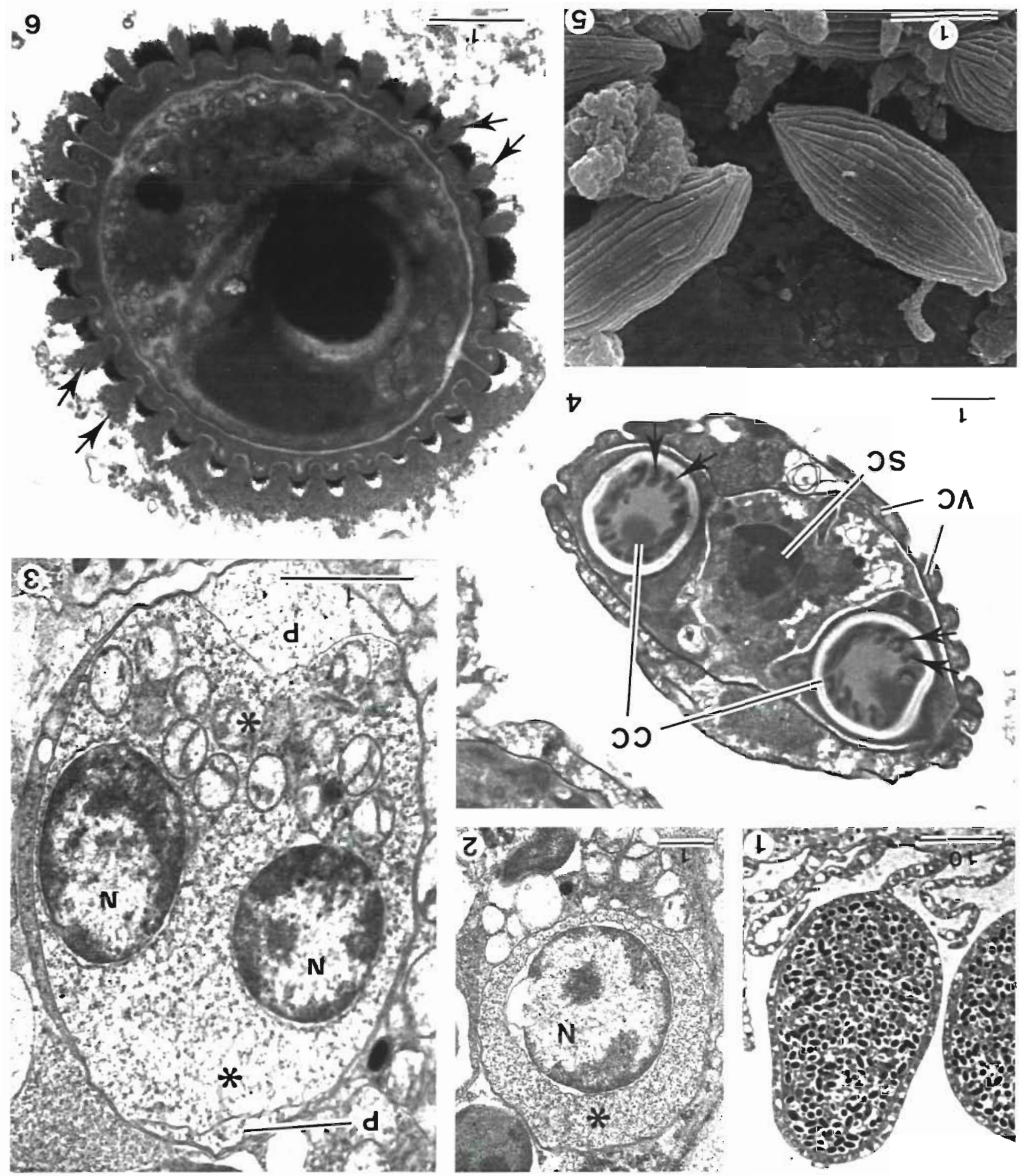
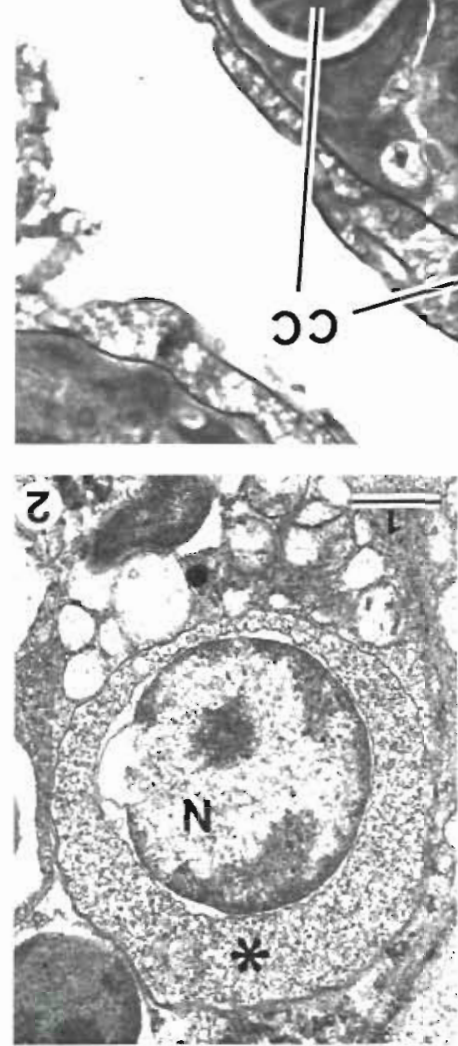

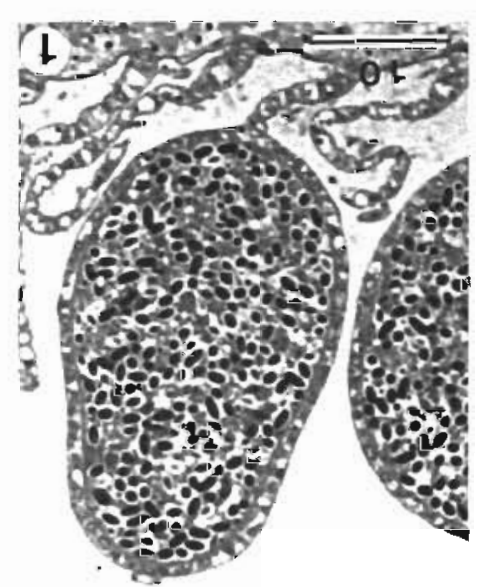



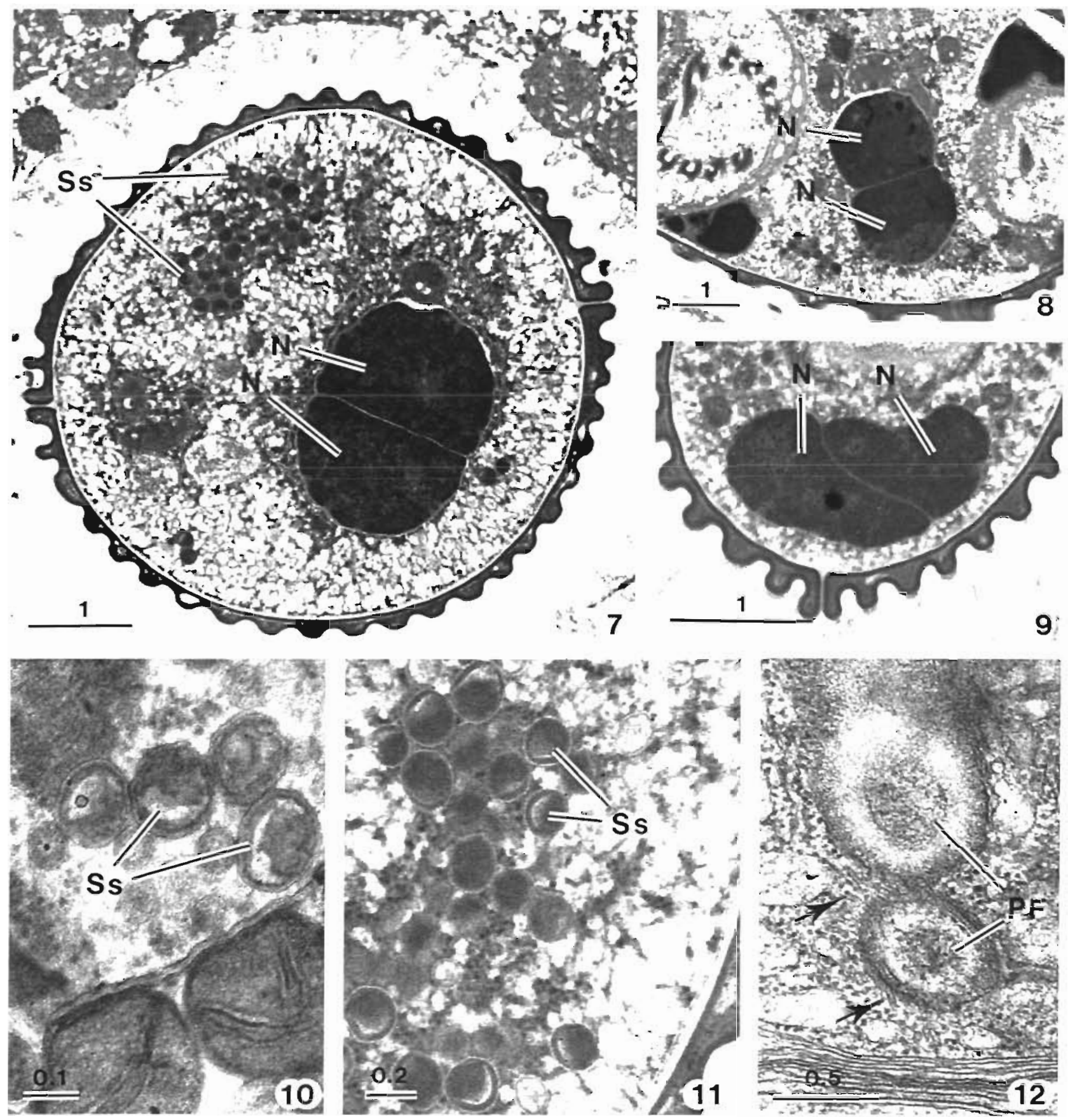

Figs 7 to 12 Myxidum glardl Flg. 7. Transverse section of a generative cell with 2 nuclei (N) arranged in diplokaryon. Several sporoplasmosomes (Ss) can be seen in the cytoplasm. Figs. 8, 9. Two aspects of the diplokaryotic association. Figs. 10, 11. Details of the sporoplasmosomes (Ss). Fig. 12. Several microtubules (arrows) surrounding the external polar filament (PF). Scale bars are labelled in um

SEM Hine (1980), in his review of eel myxidia, showed that the number of ndges alone, whether identical or different in various populations, cannot be used for species diagnosis. The situation may be similar in other genera This suggests caution has to be taken in assigning a great taxonomic significance to the number of ridges alone
The most important finding of this study is that 2 kinds of microtubules exist in the valvogenic cells of Myxidium glardi. The 'normal' diameter microtubules comply with all those found thus far in the myxosporeans, be it in the cytoplasm of generative cells or in capsulogenic cells, where they ensheath the capsular primordum, or in valvogenic cells. The 'thin', $15 \mathrm{~nm}$ 

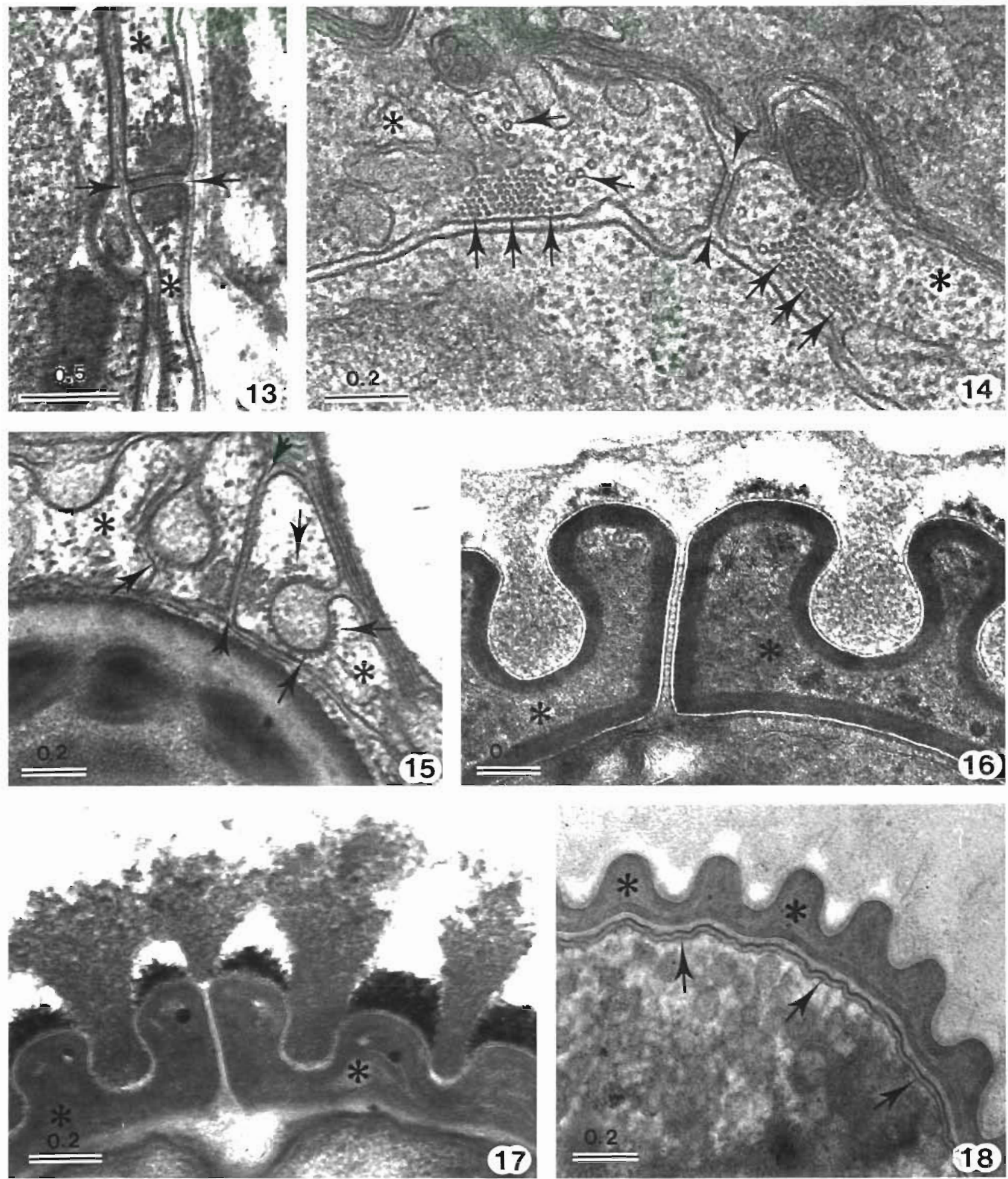

Figs. 13 to 18. Myxidium giardi. Fig. 13. Detals of the suture (arrows) between the 2 valvogenic cells (*) Fig. 14. Two valvogenic cells $(*)$ showing 2 kinds of microtubules (arrows). Between these 2 cells a septate desmosome in sutural line can be seen (arrowheads). Fig. 15. A microtubular manchette (arrows) organized in deep furrows near a septate desmosome (arrowheads) differentiated between 2 valvogenic cells ( $*$ ). Fig 16 The valvogenic cells ( $*$ ) assume electron-dense appearance Fig 17 Top of the valvogenic cell ridges (*) showing electron-dense matenal Fig. 18. Equatonal transverse section of a mature spore, showng the sporoplasm reinforced by an additional membrane in close contact with the valves (*) Scale bars are labelled in $\mu \mathrm{m}$ 
microtubules have, however, to our knowledge never been recorded in myxosporeans. Thus in Sphaeromyxa cf. magna, microtubules of 25 to $30 \mathrm{~nm}$ diameter were found both in valvogenic cells underlying the nascent shell grooves and ensheathing the external tube of the capsular primordium (Lom 1969). In Thelohanellus nikolskii, Desser et al. (1983) observed microtubules in the edges of the valvogenic cells, near the suture. Their diameter can be calculated from the magnification given to be about $23 \mathrm{~nm}$.

The width of microtubules in animal cells is known to be within the range 20 to $30 \mathrm{~nm}$. The hitherto known myxosporean microtubules comply with these values. While an early paper (Pochon-Masson 1967) mentioned a range of 15 to $30 \mathrm{~nm}$, recent sources (e.g. Dustın 1984) give the typical outer diameter in microtubules to be $24 \pm 2 \mathrm{~nm}$, consisting of 13 protofilaments. The number of protofilaments may vary from 11 to 16 (Schliwa 1986) which accounts satisfactorily for the outer diameter variation. Considering that the protofilament diameter is $5 \mathrm{~nm}$, one can calculate that at an outer diameter of $15 \mathrm{~nm}$ the number of protofilaments (which we could not decipher in our electron micrographs) is only 6 . Microtubules $15 \mathrm{~nm}$ wide functionally specialized to fit between the grooves of the capsulogenic cells seem to be a remarkable exception.

Cell junctions connecting the valvogenic cells are very often of the septate type and Myxidium giardi complies with this type. The detailed structure of these junctions has only rarely been explored (Desportes \& Nicolas 1983) and there is certainly a variety of structural modifications. Cell junctions between the valvogenic cells themselves and between the valvogenic cells and the apical parts of the capsulogenic cells can be regarded as one of the characters distinguishing myxosporeans from the majority of protists. In all Myxosporea, the junction is invariably characterised by deposition of electron-dense material beneath the cell membrane, and between the cell membranes. Junctions in $M$. giardi with the septate arrangement of the material interposed between the 2 contacting membranes are intermediate between the very simple junctions with a thin deposit of dense material situated between the membranes and underlying them, and between very elaborate junctions such as in Thelohanellus nikolskii (Desser et al. 1983). In the latter, multilayered fibrillar structures are attached to the cytoplasmic face of the membranes.

In most myxosporeans studied, including Myxidium spp. the plane of the junctions of valvogenic cells, manifested as the suture line, is set in a plane perpendicular to the spore circumference. In some myxosporeans, such as Fabespora spp. (Weidner \& Overstreet 1979), or multivalvulids such as Kudoa paniformis (Stehr 1986) and Unicapsula spp. (Schubert et al. 1975), the junction occurs between the thin, widely overlapping edges of the valvogenic cell and is extremely oblique or almost parallel to the spore circumference. The structure and orientation of the junction, i.e of the suture, may be a very important taxonomic character

The data obtained on spore formation in Myxidium giardi indicate that some of the pansporoblasts produce just one spore. This is at variance with other myxidia (Lom \& de Puytorac 1965, Uspenskaya 1969, Dyková et al. 1987) but also with other pansporoblast-forming species (reviewed by Lom et al. 1986). Hulbert et al. (1977) did not record monosporic pansporoblasts in $M$. giardi.

The sporoplasmosomes of Myxidium giardi comply with similar dense bodies found in sporoplasms of most if not all myxosporeans. No definite clue to their origin was found. However, the dense bodies occurring in the primary cells of the proliferative kidney disease of salmonids seem to have their origin in Golgi complexes (Smith et al. 1984). It may be speculated that this could also be the source of other sporoplasmosomes, since the Golgi is a normal constituent of myxosporean cells including the sporoplasm, as noted previously by Kheissin et al. (1961). The absence of detectable polysaccharides separates these inclusions from morphologically similar haplosporosomes, inclusions typical of the order Haplosporida (Azevedo 1984). The role of both types of inclusions, however, has not yet been satisfactorily resolved.

Acknowledgements. This work was partially supported by grants from the Centro de Morfologia Experimental - Instituto Nacional de Investigação Científica, Junta de Investigaçào Científica e Tecnológica, and University of Oporto.

\section{LITERATURE CITED}

Azevedo, C. (1984). Ultrastructure of the spore of Haplosporidium lusitanicum sp. n. (Haplosporida, Haplosporidiidae), parasite of a marine mollusc. J. Parasitol. 70 : 358-371

Desser, S. S., Molnar, K., Weller, I. (1983). Ultrastructure of sporogenesis of Thelohanellus nikolskii Akhmerov, 1955 (Myxozoa: Myxosporea) from the common carp. Cyprinus carpio. J Parasitol. 69: 504-518

Desportes, I., Nicolas, G. (1983). La junction septée d'un modêle pentacellulaire: la spore myxosporidienne. J. Protozool. 30, 65A, Abstr. 242

Dustin, P. (1984). Microtubules, 2nd edn. Springer Verlag, Berlin, p. 482

Dyková, 1., Lom, J., Grupcheva, G. (1987). Pathogenicity and some structural features of Myxidium rhodei (Myxozoa: Myxosporea) from the kidney of the roach Rutilus rutilus. Dis. aquat. Org. 2: 109-115

Hine, P. M. (1978). Variations in the spores of Myxidium zealandicum Hine, 1975 (Protozoa: Myxosporidea). N. Z. JI mar Freshwat. Res. 12: 189-195

Hine, P. M. (1979). Factors affecting the size of spores of 
Myxidium zealandicum Hine, 1975 (Protozoa: Myxosporida). N. Z. Jl mar. Freshwat. Res. 13: 215-223

Hine, P. M. (1980). A review of some species of Myxidium Bütschli, 1882 (Myxosporea) from eels (Anguilla spp.). J Protozool. 27: 260-267

Hulbert, W. C., Komourdjian, M. P., Moon, T. W., Fenwick, J. C (1977). The fine structure of sporogony in Myxidium zealandicum (Protozoa: Myxosporidia). Can. J. Zool. 55: 438-447

Kheissin, E. M., Shulman, S. S., Vinnitchenko, L. P. (1961). Ultrastructure of Myxobolus-spore. Citologia 3: 662-667 (Russian)

Lo, C. F. (1981). A myxidian parasite found in the eel kidney. NSC Symp. Ser. no. 3. Proc. R.O.C. U.S. Coop. Sci. Sem. Fish Dis. Nat. Sci. Council Taipei, Taiwan, p. 27-31

Lom, J. (1969). Notes on the ultrastructure and sporoblast development in fish paraziting myxosporidian of the genus Sphaeromyxa. Z. Zellforsch. 97: 416-437

Lom, J., de Puytorac, P. (1965). Studies on the myxosporidian ultrastructure and polar capsule development. Protistologica 1: 53-65

Lom, J, Molnár, K., Dyková, I. (1986). Hoferellus gilsoni (Debaissieux, 1925) comb. n. (Myxozoa, Myxosporea): redescription and mode of attachment to the epithelium of the urinary bladder of its host, the European eel. Protistologica 22: 405-413
Pochon-Masson, J. (1967). Structure et fonctions des infrastructures cellulaires dénommées 'microtubules' Année biol. 6 (Ser. 4): 361-390

Schliwa, M. (1986). The cytoskeleton. An introductory survey Springer Verlag, Wien, New York, p. 326

Schubert, G., Sprague, V., Reinboth, R. (1975). Observations on a new species of Unicapsula (Myxosporida) in the fish Maena smaris (L.) by conventional and electron microscopy. Z. ParasitKde 46: 245-252

Smith, C. E., Morrison, J. K., Ramsey, H. W., Ferguson, H. W (1984). Proliferative kidney disease: first reported outbreak in North America. J. Fish Dis. 7. 207-216

Stehr, C. (1986). Sporogenesis of the myxosporean Kudoa paniformis Kabata, Whitaker, 1981 infecting the muscle of the Pacific whiting, Merluccius productus (Ayres). J. Fish Dis. 9: 493-504

Thiéry, J.-P. (1967). Mise en évidence des polysaccharides sur coupes semifines en microscopie éléctronique. J. Microscopie 6: $987-1018$

Uspenskaya, A. V (1969). Ultrastructure of some stages of Myxidium gasterostei. Acta Protozool. 7: $71-79$ (Russian)

Weidner, E., Overstreet, R. M. (1979). Sporogenesis of a myxosporidian with motile spores. Cell Tissue Res. 201: $331-343$ 